METHODS FOR ESTIMATING GROUND-WATER PUMPAGE FOR IRRIGATION By Steven A. Frenzel

U.S. GEOLOGICAL SURVEY

Water-Resources Investigations Report 83-4277

Boise, Idaho 


\section{U.S. DEPARTMENT OF THE INTERIOR

\author{
WILLIAM P. CLARK, Secretary
}

GEOLOGICAL SURVEY

Dallas L. Peck, Director

For additional information, write to:

Idaho Office Chief

U.S. Geological Survey, WRD 230 Collins Road Boise, ID 83702

(208) $334-1750$
Copies of this report may be purchased from:

Open-File Services Section Western Distribution Branch U.S. Geological Survey Box 25425, Federal Center Denver, CO 80225 (303) 234-5888 
Abstract................................ 1

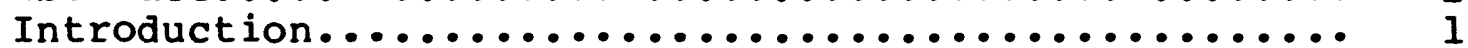

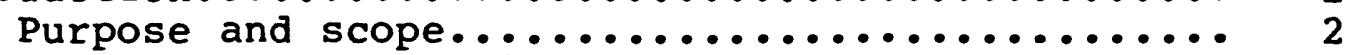

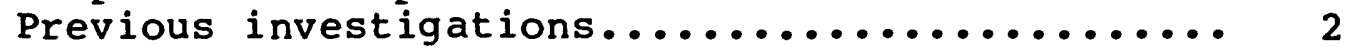

Description of estimation methods

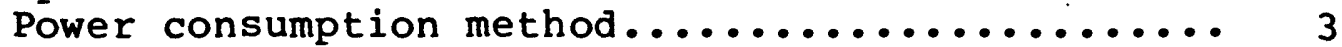

Crop-consumptive use method................. 5

Instantaneous discharge method................ 7

Applicability ............................... 7

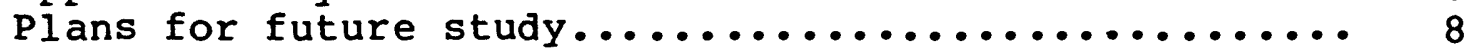

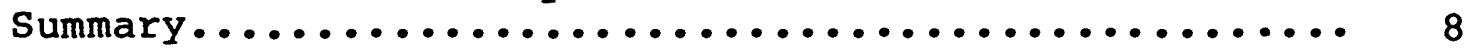

References cited............................... 10 


\section{CONVERSION FACTORS}

For readers who prefer to use metric units, conversion factors for terms used in this report are listed below:

Multiply

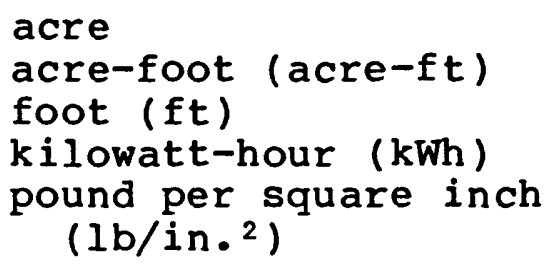

\section{To obtain}

square meter
cubic meter
meter
joule
kilopascal.




\title{
METHODS FOR ESTIMATING GROUND-WATER PUMPAGE FOR IRRIGATION
}

\author{
By \\ Steven A. Frenzel
}

\section{ABSTRACT}

Ground-water pumpage must be determined for many hydrologic and water-management studies. Although pumpage may be estimated by several methods, estimates made by more than one method may not be comparable.

Methods for estimating ground-water pumpage for irrigation include (1) power consumption, (2) crop-consumptive use, and (3) instantaneous discharge. Applicability of each method is a function of the validity of assumptions, ease of data collection, and data accuracy. Where pumping lifts are constant throughout an irrigation season, the power consumption method, which uses power consumption records, or the instantaneous discharge method, which uses mean discharge from field measurements and pump operating time, would be appropriate for estimating pumpage. Where pumping lifts fluctuate, the crop-consumptive use method, which uses crop and climatic data, would be appropriate.

\section{INTRODUCTION}

Irrigated agriculture is the largest use of water in the Western United States. Where surface-water supplies are inadequate to meet irrigation demands, ground water can provide a supplemental supply. In Idaho, excessive groundwater pumpage prompted the Idaho Department of water Resources to designate eight Critical Ground-Water Areas. Presently, pumpage is measured in only one of those areas. As demand for ground water increases, accurate estimates of pumpage are required.

Ground-water pumpage must be determined for many hydrologic and water-management studies. Determination of pumpage is rarely a primary objective; more often, pumpage is determined as a discharge component for a water 
budget. In areas where ground-water levels are declining and withdrawals are limited, it may be necessary to accurately monitor pumpage of individual wells. This may be accomplished either by installing totalizing flow meters at each pumping site or by estimating pumpage using one of several methods. Accuracy, reliability, and costs of various methods for estimating pumpage are not well known, and estimates made by more than one method may not be comparable.

\section{Purpose and Scope}

Purposes of this report are to describe existing methods for estimating ground-water pumpage for irrigation and to identify assumptions, limitations, and data requirements inherent in each method. Methods described within the scope of this report are (1) power consumption, (2) cropconsumptive use, and (3) instantaneous discharge. Other methods and many variations of each method exist, but these three are the most general and widely applicable.

Subsequent reports will compare estimated pumpage to known pumpage considering accuracy, applicability, and costs; and develop a statistical model of relations between independent variables, such as crop type and pumping lift, and the dependent variable, pumpage.

\section{Previous Investigations}

Norvitch, Thomas, and Madison (1969) computed groundwater pumpage on the Snake River Plain, Idaho, as an element of a water budget. Pumpage for part of the plain was estimated from irrigated acreage and an average water use figure, and pumpage for the remaining area was estimated from power consumption data.

Ogilbee and Mitten (1970) compared metered pumpage to pumpage estimated from power consumption data and observed the difference to be less than 10 percent for areas of one-quarter township and one township. Comparisons made for individual sections (one thirty-sixth township) showed that estimated pumpage ranged from 37 percent less to 83 percent more than metered pumpage.

Young and Harenberg (1971) estimated ground-water pumpage for the Snake Plain aquifer, Idaho. Most of the water pumped from the aquifer was used for irrigation. Power consumption and average discharges for a sample of randomly selected wells were used to estimate kilowatt-hours required to pump 1 acre-ft of water. This factor then was applied to total power consumed by irrigation wells on the plain to estimate total ground water pumped for irrigation. 
Heimes and Luckey (1982) estimated historical groundwater pumpage from the High Plains aquifer by using irrigation demand and irrigated acreage. Irrigation demand, or crop-consumptive use, was estimated using the modified Blaney-Cridale method (U.S. Soil Conservation Service, 1967) and long-term average climatic data.

Diamond and williamson (1983) estimated yearly groundwater pumpage for the Central Valley, California, from 1961 to 1977 using existing estimates based on power consumption records. A multiple linear-regression model, which used the relation between ground-water pumpage and climatic indices, provided pumpage estimates including periods where power records were not available.

Many studies have been done on crop-consumptive use, but few, if any, have determining ground-water pumpage as an objective. Most studies focus upon water requirements of a particular crop for a given area. In some studies, such as that by Sutter and Corey (1970), irrigation efficiencies are assumed, thereby providing an estimate of irrigation requirements.

\section{DESCRIPTION OF ESTIMATION METHODS}

\section{Power Consumption Method}

Power consumption at a pumping site is related directly to pump efficiency, total lift of water, pressure head, and amount of water pumped. Expressed mathematically (Moreland, 1976, p. 13):

where

$$
\begin{aligned}
& k W h=E \times\left[\left(H_{o}-H_{p}\right)+P_{h}\right] \times Q, \text { or } \\
& Q=\frac{k W h}{E \times\left[\left(H_{0}^{-H_{p}}\right)+P_{h}\right]},
\end{aligned}
$$

$$
\begin{aligned}
& \text { kWh = power consumed, in kilowatt-hours; } \\
& \mathrm{E} \quad \text { = pump efficiency, in kilowatt-hours per foot } \\
& \text { of lift per acre-foot of water pumped; } \\
& \left(\mathrm{H}_{\mathrm{O}}-\mathrm{H}_{\mathrm{p}}\right)=\text { lift from the pumping level, } \mathrm{H}_{\mathrm{p}} \text {, to } \mathrm{I} \text { and sur- } \\
& P_{h} \quad=\text { pressure head at land surface, in feet of } \\
& \text { water; and, } \\
& \text { Q } \quad \text { total amount of water pumped, in acre-feet. }
\end{aligned}
$$

An assumption of this method is that pumping lift and efficiency remain relatively constant throughout the irrigation season. Pumping lift is the sum of static water level, drawdown, and discharge pressure head. Another 
assumption is that water is discharged continuously while the pump is operating (no priming time). These assumptions may restrict the suitability of this method where pumping lifts vary considerably throughout the irrigation season and where priming time constitutes a substantial part of the total pump operating time.

Calculation of pumpage for each well or group of wells thus requires a knowledge of lift, pressure head, pumping efficiency, and power consumed. Pressure head can be estimated if irrigation method is known (Moreland, 1976, p. 13). Young and Harenberg (1971) measured pressure head at 124 wells supplying conventional sprinkler systems on the Snake River Plain and determined that the average pressure was about $55 \mathrm{lb} / \mathrm{in}^{2}$. Center-pivot sprinklers on the plain operate at about $90 \mathrm{lb} / \mathrm{in} .{ }^{2}$ pressure (Moreland, 1976, p. 13). Sprinkler-irrigation systems currently being installed operate at pressures from $45 \mathrm{lb} / \mathrm{in}^{2}{ }^{2}$ (low-pressure centerpivot) to $80 \mathrm{lb} / \mathrm{in}^{2}$ (high-pressure center-pivot). Conventional sprinklers operate at 65-70 lb/in. ${ }^{2}$ (Sprinkler Irrigation Sales, Inc., Nampa, Idaho, oral commun., 1983). Young and Harenberg (1971) also collected pumping efficiency data from 155 wells on the Snake River Plain. They determined that pumping efficiency ranged from 1.2 to 3.9 $\mathrm{kWh} /$ acre-ft per foot of $\mathrm{lift}$ and averaged $2.06 \mathrm{kWh} / \mathrm{acre}-\mathrm{ft}$ per foot of lift.

Most irrigation pumps are electrically powered. Power consumption records can be obtained from utility companies, but individual accounts are not identified to protect the confidentiality of landowners. In some cases, it may be possible to obtain total power consumption by reading power meters at the well site before and after the irrigation season.

Pumping 1 ift can be estimated or measured. Static water levels can be estimated from water-level contour maps or from reported information. Drawdown can be estimated from pump tests conducted when an irrigation system is installed or as part of a previous study. Pressure head can be estimated from information about the irrigation system design. All components of pumping lift can be measured in the field.

Pumping efficiency can be estimated or measured. Estimates are based on reported information or on average efficiencies observed in studies of similar areas. Utility and irrigation equipment companies may conduct efficiency tests as a service to their customers, and this information can be used to help estimate pumping efficiency. 


\section{Crop-Consumptive Use Method}

Crop-consumptive use is the amount of water transpired in the process of plant growth plus water evaporated from soil and foliage in the area occupied by growing plants (Sutter and Corey, 1970, p. 1). The term nevapotranspiration" often is used synonymously with "crop-consumptive use." Crop-consumptive use or evapotranspiration can be estimated by many methods. Robinson and Johnson (1961) compiled a bibliography of several hundred papers on the subject. Many empirical formulas exist that relate climatic variables to crop-consumptive use ( $\mathrm{Bl}$ aney and Criddle, 1950; Jensen and Haise, 1963; Munson, 1966; and U.S. Soil Conservation Service, 1967).

The modified Blaney-Criddle method (U.S. Soil Conservation Service, 1967) has been used successfully in Idaho (Sutter and Corey, 1970, p. 3). The equation is:

$$
u=0.01 t p k_{c}(0.0173 t-0.314)
$$

where

$\mathbf{u}=$ monthly crop-consumptive use, in feet;
$t=$ mean monthly temperature, in degrees Fahrenheit;
$\mathrm{p}=$ monthly percentage of annual daylight hours; and
$\mathbf{k}_{\mathbf{c}}=$ crop growth-stage coefficient.

Assumptions made when using the modified Blaney-Criddle equation (Sutter and Corey, 1970, p. 5) are:

1. Seasonal or monthly crop-consumptive use requirement is proportional to the climatic factor $(0.01 \mathrm{tp})$.

2. Crop production is not limited by an inadequate water supply at any time during the growing season.

3. All factors other than temperature, percentage of daylight hours, and growing season are constant.

To relate crop-consumptive use to pumpage, three other factors must be determined:

1. Irrigated acreage, usually reported in acres by crop type.

2. Irrigation efficiency, which is the percentage of water pumped that is consumptively used. 
3. Effective precipitation, which is the amount of water from precipitation that is capable of satisfying part of the crop-consumptive use.

Pumpage is calculated as follows:

where

$$
P=(U-e p)(A)(I)
$$

$$
\begin{aligned}
& \mathrm{P}=\text { pumpage, in acre-feet; } \\
& \mathrm{U}=\text { crop-consumptive use, in feet; } \\
& \text { ep = effective precipitation, in feet; } \\
& \mathrm{A}=\text { irrigated acreage, in acres; and } \\
& \mathrm{I}=\text { irrigation efficiency. }
\end{aligned}
$$

Data requirements of the modified Blaney-Criddle consumptive use method (U.S. Soil Conservation Service, 1967) are:

1. Irrigated acreage by crop type

2. Irrigation efficiency

3. Mean monthly temperature

4. Crop growth-stage coefficient

5. Monthly percentage of annual daylight hours

6. Growing season

7. Effective precipitation

Irrigated acreage may be determined by remote sensing, field observation, or reported information. Remote-sensing techniques such as infrared satellite photos can be useful for large study areas. Field observations are limited to small study areas owing to time constraints. Investigators are not restricted to one data collection technique, and often a combination of techniques is used.

Irrigation efficiency usually is estimated and is a function of irrigation methods, management practices, and infiltration rates. In areas where gravity (ditch and furrow) systems predominate, irrigation efficiency may be measured. Field observations of irrigation methods and management practices may produce reasonable estimates of irrigation efficiency.

Climatic data normally are not collected onsite in ground-water use studies. The National Weather Service has an extensive network of stations across the United States where temperature and precipitation data are collected. At some stations, more extensive data such as wind direction and velocity, evaporation, and humidity are collected. An advantage of using the modified Blaney-Criddle equation (U.S. Soil Conservation Service, 1967) is that the only climatic variables required are temperature and precipitation. 
Remote-sensing techniques, field observations, and reported information may provide detailed crop-related data. Sources of crop information are generally the same as for irrigated acreage information. Solar radiation, or percentage of daylight hours, was reported by the U.S. Soil Conservation Service (1967).

Determining pumpage by the crop-consumptive use method is most effective where detailed climatic and crop data are readily available and irrigation efficiencies are well known.

\section{Instantaneous Discharge Method}

Measurements of instantaneous discharge from a well can be extrapolated to estimate seasonal pumpage. Seasonal pumpage is equal to mean instantaneous discharge $t i m e s$ total pump operating time.

Data requirements of this method are minimal; instantaneous discharge and pump operating time are needed. Discharge measurements may be made with in-line flow meters, nonintrusive (such as acoustic) flow meters, or in open channels with current meters, weirs, or flumes. Pump operating time may be determined with built-in timers or vibrating time totalizers.

One assumption of this method is that a single measurement or the mean of several instantaneous discharge measurements accurately approximates true seasonal mean discharge. Instantaneous discharge is a function of many factors, principally pumping lift and pump speed. Discharge pressure (a component of pumping lift) can be regulated during the irrigation season to adjust for changing water requirements. As in the power consumption method, it is assumed there is no priming time.

This method is similar to the power consumption method and selected discharge measurements often are used to estimate pumping efficiency for a population of wells.

\section{AP PL ICABILITY}

Applicability of each method is a function of the validity of assumptions, ease of data collection, and data accuracy. Where data required for one method are not available or are prohibitively expensive to obtain, an alternate method can be used. 
The power consumption method is best suited to areas where pumping lifts are fairly constant throughout an irrigation season and where power consumption records are available on an individual well basis. This method is not well suited to areas where power consumption records may include power consumed for purposes other than pumping ground water for irrigation.

The crop-consumptive use method is best suited to areas where complete and accurate climatic and crop acreage records are available. These areas also must be under management practices such that crops receive about 100 percent of the crop-water requirements. Where ground water is used to supplement surface water for irrigation, it is necessary to determine the quantity of surface water diverted. Further, because it is necessary to accurately estimate irrigation efficiency, variations in soil characteristics and irrigation system type should be minimal.

The instantaneous discharge method, like the power consumption method, is suited to areas where pumping lifts are relatively constant. This method may be preferred if discharge measuring conditions are good, if the study area is small enough to allow multiple discharge measurements on each pumping well, or if power consumption records are inadequate.

\section{PLANS FOR FUTURE STUDY}

Estimated pumpage will be compared to known pumpage during the 1983 irrigation season on the Snake River Plain in southern Idaho. Comparisons will be made on the basis of cost, accuracy, and applicability of each method. Study areas will be selected to represent a variety of conditions that exist across the plain.

\section{SUMMARY}

Ground-water pumpage must be determined for many hydrologic and water-management studies. Pumpage can be estimated by several methods; however, estimates made by more than one method may not be comparable.

Commonly used methods for estimating ground-water pumpage for irrigation include:

--Power consumption method: Electrical power used to pump 1 acre-ft of water is divided into the total power used for irrigation in a study area. 
--Crop-consumptive use method: Water required to bring a crop to maturity is calculated using crop type and climatic variables. By applying an irrigation efficiency to the calculated water requirement, a pumpage estimate is determined.

--Instantaneous discharge method: One or more instantaneous discharge measurements are made at each well during an irrigation season and the (mean) discharge is multiplied by total pump operation time to obtain seasonal pumpage.

Applicability of each method is a function of the validity of assumptions, ease of data collection, and data accuracy. Where pumping lifts are constant, either the power consumption method or the instantaneous discharge measurement method would be appropriate. Where pumping lifts fluctuate, the crop-consumptive use method would be appropriate.

A comparison of estimated and known pumpage on the basis of cost, accuracy, and applicability of each method will be made during the 1983 irrigation season. 


\section{REFERENCES CITED}

Blaney, H. F., and Criddle, W. D., 1950, Determining water requirements in irrigated areas from climatological and irrigation data: U.S. Department of Agriculture, Soil Conservation Service, Technical Paper 96, 48 p.

Diamond, Jonathan, and Williamson, A. K., 1983, A summary of ground-water pumpage in the Central Valley, California, 1961-1977: U.S. Geological Survey Water-Resources Investigations Report 83-4037 (in press).

Heimes, F. J., and Luckey, R. R., 1982, Method for estimating historical irrigation requirements from ground water in the High Plains in parts of Colorado, Kansas, Nebraska, New Mexico, Oklahoma, South Dakota, Texas, and Wyoming: U.S. Geological Survey Water-Resources Investigations Report $82-40,64$ p.

Jensen, M. E., and Haise, H. R., 1963, Estimating evapotranspiration for various crops using solar radiation: American Society of Civil Engineers, Journal of the Irrigation and Drainage Division, v. 89, no. IR4, p. 15-41.

Moreland, J. A., 1976, Digital-model analysis of the effects of water-use alternatives on spring discharges, Gooding and Jerome Counties, Idaho: Idaho Department of Water Resources, Water Information Bulletin no. 42,46 p.

Munson, W. C., 1966, Estimating consumptive use--Munson P.E. index method, in Methods for Estimating Evapotranspiration Symposium, Las Vegas, 1966, Proceedings: American Society of Civil Engineers, Irrigation and Drainage Specialty Conference, p. 65-107.

Norvitch, R. F., Thomas, C. A., and Madison, R. J., 1969, Artificial recharge to the snake Plain aquifer in Idaho; an evaluation of potential and effect: Idaho Department of Reclamation, Water Information Bulletin no. $12,59 \mathrm{p}$.

Ogilbee, William, and Mitten, H. T., 1970, A continuing program for estimating ground-water pumpage in California--methods: U.S. Geological survey, Open-File Report, 22 p.

Robinson, T. W., and Johnson, A. I., 1961, Selected bibliography on evaporation and transpiration: U.S. Geological Survey, Water-Supply Paper 1539-R, 25 p. 
Sutter, R. J., and Corey, G. L., 1970, Consumptive irrigation requirements for crops in Idaho: Moscow, Idaho, University of Idaho, College of Agriculture, Bulletin $516,97 \mathrm{p}$.

U.S. Soil Conservation Service, 1967, Irrigation water requirements: U.S. Department of Agriculture, Technical Release no. 21,88 p.

Young, H. W., and Harenberg, W. A., 1971, Ground-water pumpage from the Snake Plain aquifer, southeastern Idaho: Idaho Department of Water Administration, Water Information Bulletin no. 23, 28 p. 